\title{
PENGARUH MARKET VALUE TERHADAP HOLDING PERIOD SAHAM PADA PERUSAHAAN FOOD AND BEVERAGES YANG TERDAFTAR DI BURSA EFEK INDONESIA PERIODE 2010-2012
}

\author{
Ingrid Fransisca Leleng \\ Ventje Ilat \\ Heince Wokas \\ Fakultas Ekonomi dan Bisnis Jurusan Akuntansi \\ Universitas Sam Ratulangi Manado \\ email : louisca06@yahoo.com
}

\begin{abstract}
ABSTRAK
Menyadari perlunya pertimbangan seorang investor dalam mengambil keputusan untuk menentukan masa kepemilikan (holding period) suatu saham yang dimilikinya, maka sangat penting bagi investor untuk memahami faktor-faktor yang mempengaruhi holding period saham. Adapun tujuan dari penelitian ini adalah untuk mengetahui pengaruh Market Value terhadap Holding Period saham. Teknik analisis yang digunakan adalah analisis regresi linier sederhana. Berdasarkan hasil penelitian, bahwa perubahan Holding Period untuk tahun 2010-2012 hanya sebesar 14.651. Hasil pengujian hipotesis uji t dan uji f menyatakan $\mathrm{H}_{0}$ diterima dan $\mathrm{H}_{\mathrm{a}}$ ditolak karena nilai yang diperoleh $0,748>\alpha=0,05$. Hasil koefisien determinasi $\left(R^{2}\right)$ adalah sebesar 0,004 , memberikan pengertian bahwa besarnya Holding Period pada perusahaan Food and beverages dapat dijelaskan oleh variabel independen yaitu Market Value adalah sebesar $0.4 \%$ sementara sisanya 99,6\% dijelaskan oleh variabel lain yang tidak diteliti dalam penelitian ini. Jadi, hasil dari pengujian dalam penelitian ini menyatakan bahwa Market Value tidak berpengaruh terhadap Holding Period dalam perusahaan.
\end{abstract}

\section{Kata Kunci : Market Value, Holding Period}

\begin{abstract}
Recognizing the need for consideration of an investor in making decisions to determine the ownership period ( holding period) a share holding, it is very important for investors to understand the factors that affect stock holding period. The purpose of this study was to determine the effect of the Holding Period Market Value stocks. The analysis technique used is simple linear regression analysis. Based on the results of the study, that changes Holding Period for the 2010-2012 year only amounted to 14.651. The results of hypothesis testing and test $f t$ test states $\mathrm{HO}$ is accepted and Ha is rejected because the value obtained 0,748> $\alpha=0,05$. The coefficient of determination ( $R 2)$ is equal to 0,004, giving the sense that the magnitude of Holding Period on Companies Food and beverages can be explained by the independent variables, Market Value is at $0.4 \%$ while the remaining $99.6 \%$ is explained by other variables not examined in the study this. Thus, the results of the testing in this study stated that the Market Value has no effect on the company's Holding Period.
\end{abstract}

Keyword : Market Value, Holding Period 


\section{PENDAHULUAN}

\section{Latar Belakang}

Berinvestasi merupakan salah satu kegiatan favorit beberapa kalangan masyarakat tertentu karena dianggap dapat menghasilkan uang dengan cara yang mudah dan dalam jumlah yang besar asalkan dilakukan secara tepat. Menurut Sunariyah, (2003) Investasi adalah penanaman modal untuk satu atau lebih aktiva yang dimiliki dan biasanya berjangka waktu lama dengan harapan mendapatkan keuntungan di masa-masa yang akan datang.

Sejak tahun 1989, perusahaan penerbit saham (emiten) sebagai perusahaan yang membutuhkan modal dan investor sebagai penanam modal mulai melirik pasar modal (miapuspita, 2003). Pemerintah telah mengambil kebijakan menciptakan banyak peluang investasi dan mendorong perkembangan jumlah emisi saham dalam upaya untuk meningkatkan kegiatan pasar modal. Hal ini mencerminkan banyaknya perusahaan yang mencatatkan diri pada bursa saham serta tingginya volume transaksi perdagangan dan saham yang beredar meningkat. Keputusan penanaman modal tersebut dapat dilakukan oleh individu atau suatu entitas yang mempunyai kelebihan dana. Pada dasarnya, pasar modal merupakan tempat yang menjembatani antara pihak yang kelebihan dana kepada pihak yang kekurangan dana. Dana tersebut dapat digunakan untuk ekspansi usaha atau untuk memperbaiki struktur modal perusahaan. Dengan demikian pasar modal dapat sebagai sumber alternative keuangan bagi investor untuk mendukung pertumbuhan ekonomi nasional (Gudono dan Hidayanti, 2003).

Dalam melakukan kegiatannya Investor atau pemilik saham memiliki kebebasan untuk memilih jenis saham perusahaan yang go public. Selain memilih saham, investor juga memiliki kebebasan dalam membeli jumlah lembar saham dan lamanya memegang saham tersebut. Akan tetapi investor harus memiliki pertimbangan untuk mengurangi resiko sampai tingkat tertentu untuk mendapatkan gain yang maksimal. Salah satu pertimbangan penting yang terkait dengan keputusan investasi saham bagi seorang investor adalah penetuan masa kepemilikan (holding period saham). Holding period diartikan sebagai lamanya investor menahan dananya pada saham tertentu untuk waktu tertentu. Variabel market value menurut leny dan indrianto (1990) mempengaruhi variabel holding period, dimana perusahaan yang memiliki market value yang semakin kecil (besar) cenderung mempunyai holding period yang semakin pendek (panjang). Untuk variabel resiko saham menurut Subali dan Zuhroh (2002) dimana perusahaan yang mempunyai resiko saham yang semakin kecil (besar) cenderung mempunyai holding period yang semakin panjang (pendek). Variabel market value berpengaruh positif dan signifikan terhadap keputusan investor dalam menentukan masa kepemilikan sahamnya.

Dalam menentukan apakah investor akan melakukan transaksi di pasar modal, biasanya keputusan akan didasarkan pada berbagai informasi transaksi yang dimilikinya, baik informasi transaksi yang tersedia di public maupun informasi transaksi pribadi (fatmawati dan asri, 1999). Informasi transaksi tersebut akan memiliki makna atau nilai bagi investor jika keberadaan informasi transaksi tersebut menyebabkannya melakukan transaksi di pasar modal. Adanya informasi transaksi dapat mempengaruhi lamanya seorang investor menahan sejumlah dananya dalam suatu perusahaan tertentu.

\section{Tujuan Penelitian}

Tujuan dari penelitian ini adalah untuk mengetahui pengaruh market value terhadap Holding period saham pada perusahaan food beverages di BEI (2010-2012).

\section{TINJAUAN PUSTAKA}

\section{Pengertian Akuntansi}

Akuntansi adalah suatu sistem informasi yang mengidentifikasikan, mencatat, dan mengkomunikasikan kejadian ekonomi dari suatu organisasi kepada pihak yang berkepentingan (menurut Weygandtdalam Yadiati dan Wahyudi 2006: 7-8).

Horngren (2007: 4) memberikan pengertian akuntansi is the information system that measures business activities, process that information into reports communicates the result to decision makers. Atau dengan kata lain, akuntansi adalah sistem informasi yang mengukur aktivitas bisnis, proses mengenai informasi untuk menghasilkan laporan dan mengkomunikasikan hasil ke pembuat keputusan. 
Definisi lain dapat juga dipakai untuk memahami lebih dalam pengertian akuntansi ini. Dalam buku $A$ Statement of Basic Accounting Theory (ASOBAT), akuntansi diartikan sebagai berikut: "Proses mengidentifikasikan, mengukur, dan menyampaikan informasi ekonomi sebagai bahan dalam mempertimbangkan berbagai alternatif dalam mengambil kesimpulan oleh para pemakainya".Komite istilah American Institute of Certified Public accounting (AICPA) mendefinisikan akuntansi sebagai berikut: "Akuntansi adalah seni pencatatan, pengolongan, dan pengikhtisaran dengan cara tertentu dan dalam ukuran moneter, transaksi, dan kejadian-kejadian yang umumnya bersifat keuangan dan termasuk menafsirkan hasilhasilnya".Definisi ini bisa dipermasalahkan seandainya kita berhadapan dengan keadaan sistem pencatatan yang sudah menggunakan komputerisasi, apa lagi proses pengolahan datanya tidak lagi melalui pencatatan, tetapi melalui optic, scanning, dialing, ataukeyboardsehingga sama sekali tidak melibatkan proses pencatatan konvensional. Beberapa definisi tersebut sudah out of date.Accounting Principle Board (APB) Statement No. 4 mendefinisikan akuntansi sebagai berikut: "Akuntansi adalah suatu kegiatan jasa.Fungsinya adalah memberikan informasi kuantitatif, umumnya dalam ukuran uang, mengenai suatu badan ekonomi yang dimaksudkan untuk digunakan dalam pengambilan keputusan ekonomi sebagai dasar memilih di antara beberapa alternatif'(Harahap 2011: 5).

\section{Laporan Keuangan}

Menurut IAI (PSAK No.1, 2012: par.10), laporan keuangan adalah suatu penyajian terstrukturdari posisi keuangan dan kinerja keuangan suatu entitas. Tujuanlaporan keuangan adalah memberikan informasi mengenai posisikeuangan, kinerja keuangan, dan arus kas entitas yang bermanfaat bagi sebagian besar kalangan pengguna laporan dalam pembuatan keputusan ekonomi. Laporan keuangan juga menunjukkan hasil pertanggungjawaban manajemen atas penggunaan sumber daya yang dipercayakan kepada mereka. Dalam rangka mencapai tujuan tersebut, laporan keuangan menyajikan informasi mengenai entitas yang meliputi:
1. aset;
2. laibilitas;
3. ekuitas;
4. pendapatan dan beban termasuk keuntungan dan kerugian;
5. kontribusi dari dan distribusi kepada pemilik dalam kapasitasnya sebagai pemilik;dan
6. arus kas.

Informasi tersebut, beserta informasi lainnya yang terdapat dalam catatan atas laporan keuangan, membantu pengguna laporan dalam memprediksi arus kas masa depan dan, khususnya, dalam hal waktu dan kepastian diperolehnya kas dan setara kas.

Tujuan laporan keuangan menurut SAK No. 1 adalah:

1. Menyediakan informasi yang menyangkut posisi keuangan, kinerja, serta perubahan posisi keuangan suatu perusahaan yang bermanfaat bagi sejumlah besar pemakai dalam pengambilan keputusan ekonomi.

2. Laporan keuangan yang disusun untuk tujuan ini memenuhi kebutuhan bersama sebagian besar pemakai. Namun demikian, laporan keuangan tidak menyediakan semua informasi yang mungkin dibutuhkan pemakai dalam pengambilan keputusan ekonomi karena secara umum menggambarkan pengaruh keuangan dari kejadian di masa lalu, dan tidak diwajibkan untuk menyediakan informasi nonkeuangan.

Laporan keuangan juga menunjukan apa yang telah dilakukan manajemen (stewardship), atau pertanggungjawaban manajemen atas sumber daya yang dipercayakan kepadanya. Pemakai yang ingin menilai apa yang telah dilakukan atau pertanggungjawaban manajemen berbuat demikian agar mereka dapat membuat keputusan ekonomi; keputusan ini mungkin mencakup, misalnya, keputusan untuk menahan atau menjual investasi mereka dalam perusahaan atau keputusan untuk mengangkat kembali atau mengganti manajemen.

\section{Saham}

Saham dapat didefinisikan tanda penyertaan atau kepemilikan seseorang atau badan dalam suatu perusahaan atau perseroan terbatas. Wujud saham adalah selembar kertas yang menerangkan bahwa pemilik kertas tersebut adalah pemilik perusahaan yang menerbitkan surat berharga tersebut. Porsi kepemilikan ditentukan oleh seberapa besar penyertaan yang ditanamkan di perusahaan tersebut (Darmadji dan Fakhruddin, 2001: 5).

Investor yang melakukan pembelian saham, otomatis akan memiliki hak kepemilikan di dalam perusahaan yang menergitkannya. Banyak sedikitnya jumlah saham yang dibeli akan menentukan presentase 
kepemilikan dari investor tersebut. Secara umum, ada dua manfaat yang bisa diperoleh bagi pembeli saham, yaitu manfaat ekonomis dan manfaat non ekonomis.

Manfaat ekonomis meliputi perolehan deviden dan perolehan capital gain. Deviden merupakan sebagian keuntungan perusahaan yang diberikan kepada pemegang saham, sedangkan capital gain adalah keuntungan yang diperoleh investor dari hasil jual beli saham, berupa selisih antara nilai jual yang lebih tinggi dibandingkan nilai beli saham yang lebih rendah.

\section{Market Value}

Market value yang di sebut juga market price merupakan harga pada pasar rill dan merupakan harga yang paling mudah di tentukan karena merupakan harga dari suatu saham yang sedang berlangsung atau jika pasar sudah tutup, maka dapat dikatakan bahwa harga pasar adalah harga penutupannya. (closing price), (Piji Parkati dan Panji Anoraga, 2001). Nilai kapitalisasi pasar dapat diklasifikasikan sebagai berikut:
a. Kapitalisasi besar $($ big - cap)
b. Kapitalisasi sedang (mid-cap)
c. Kapitalisasi kecil (small-cap)

Nilai kapitalisasi pasar dapat diperoleh dengan mengalikan harga pasar dengan jumlah saham beredar (panji, 2001).

$$
\text { Nilai pasar }=\text { Harga Pasar } \mathbf{X} \text { Total Saham }
$$

\section{Holding Period}

Holding period adalah lamanya waktu yang diperlukan investor untuk berinvestasi dengan sejumlah uang yang bersedia dikeluarkan. Holding period juga berarti rata-rata panjangnya waktu investor menahan saham perusahaan dalam jangka waktu atau periode tertentu (Jones, 1996). Holding period merupakan variabel yang memberikan indikasi tentang rata-rata panjangnya waktu investor untuk menehan saham suatu perusahaan.

Menurut Bhide (1993) holding period akan semakin panjang bila transaction cost semakin besar karena akan menurunkan tingkat spekulasi investor dengan indikasi menurunnya volume transaksi dipasar saham. Pernyataan bhide tersebut diperkuat oleh Umlauf (1993) yang menyatakan bahwa meningkatnya transaction cost akan menurunkan tingkat turn over di pasar saham. Epps (1976) dan Jarrell (1984) menembahkan bahwa volume transaksi berbanding terbalik terhadap transaction cost dan holding period.

\section{Hubungan Antar Konsep}

Pengaruh Market Value terhadap Holding Period

Market value merupakan variabel yang selau diperhatikan oleh investor, makin besar nilai pasar suatu perusahaan, makin besar pula investor menahan kepemilikan sahamnya, karena investor masih menganggap bahwa perusahaan besar biasanya lebih stabil keuangannya, resikonya lebih kecil dan mampu menghasilkan laporan dan informasi keuangan.

Market value digunakan untuk menghitung nilai perusahaan yang menyebabkan investor mau menanamkan dananya pada suatu surat berharga. Hal ini dipergunakan untuk melihat kecenderungan investor terhadap ukuran suatu perusahaan tertentu. Disamping itu perusahaan besar diasumsikan lebih dipertimbangkan oleh investor untuk berinvestasi dari pada perusahaan kecil (HY.Hadi (Atkins dan Dly). 2008)

\section{Penelitian Terdahulu}

\begin{tabular}{|c|l|l|l|l|l|l|l|}
\hline No & $\begin{array}{c}\text { Nama } \\
\text { Peneliti/ } \\
\text { Tahun }\end{array}$ & \multicolumn{1}{|c|}{ Judul } & Tujuan & $\begin{array}{l}\text { Metode } \\
\text { Peneliti } \\
\text { an }\end{array}$ & $\begin{array}{l}\text { Hasil } \\
\text { Penelitian }\end{array}$ & Persamaan & Perbedaan \\
\hline 1 & $\begin{array}{l}\text { Helmi } \\
\text { Yulianto } \\
\text { Hadi } \\
\text { (2008) }\end{array}$ & $\begin{array}{l}\text { Analisis } \\
\text { Pengaruh } \\
\text { market value } \\
\text { terhadap } \\
\text { holding period } \\
\text { pada saham- } \\
\text { saham LQ45 } \\
\text { periode 2003- }\end{array}$ & $\begin{array}{l}\text { untuk } \\
\text { mengetahu } \\
\text { i seberapa } \\
\text { besar } \\
\text { pengaruh } \\
\text { market } \\
\text { value } \\
\text { terhadap }\end{array}$ & $\begin{array}{l}\text { Menyatakan } \\
\text { bahwa 38, 6\% } \\
\text { variasi holding } \\
\text { period dapat } \\
\text { dijelaskan oleh } \\
\text { market value }\end{array}$ & $\begin{array}{l}\text { Penelitian } \\
\text { yang } \\
\text { dilakukan oleh } \\
\text { H.Y Hadi } \\
\text { terletak pada } \\
\text { variabel- } \\
\text { variabel baik } \\
\text { dependen }\end{array}$ & $\begin{array}{l}\text { Pulianto Hadi (2005) } \\
\text { dilakukan dikhususkan } \\
\text { pada perusahaan yang } \\
\text { terdaftar pada jajaran } \\
\text { LQ45 sedangkan } \\
\text { penelitian ini }\end{array}$ \\
\hline
\end{tabular}




\begin{tabular}{|c|c|c|c|c|c|c|c|}
\hline & & 2005 & $\begin{array}{l}\text { holding } \\
\text { period } \\
\text { saham } \\
\text { perusahaan } \\
\text { yang } \\
\text { terdaftar di } \\
\text { LQ45. }\end{array}$ & & & $\begin{array}{l}\text { maupun yang } \\
\text { independen } \\
\text { serta metode } \\
\text { analitis yang } \\
\text { digunakan. }\end{array}$ & $\begin{array}{l}\text { dilakukan pada } \\
\text { perusahaan food and } \\
\text { beverage yang } \\
\text { terdaftar di BEI. }\end{array}$ \\
\hline 2 & $\begin{array}{l}\text { Yustiana } \\
\text { Andriani } \\
\text { Ayu } \\
(2008)\end{array}$ & $\begin{array}{l}\text { Pengaruh bid- } \\
\text { ask spread, } \\
\text { market value } \\
\text { dan risk of } \\
\text { return terhadap } \\
\text { holding period } \\
\text { saham (studi } \\
\text { kasus pada } \\
\text { perusahaan } \\
\text { perbankan yang } \\
\text { go public di BEI } \\
\text { periode 2005- } \\
\text { 2007). }\end{array}$ & & $\begin{array}{l}\text { regresi } \\
\text { linier } \\
\text { bergan } \\
\text { da }\end{array}$ & $\begin{array}{l}\text { variabel } \\
\text { independen tidal } \\
\text { memiliki } \\
\text { pengaruh terhadap } \\
\text { Holding period } \\
\text { saham, sedangkan } \\
\text { secara parsial } \\
\text { hanya variabel } \\
\text { bid-ask spread } \\
\text { yang mempunyai } \\
\text { Pengaruh terhadap } \\
\text { holding period } \\
\text { saham tahun } \\
\text { 2007. }\end{array}$ & $\begin{array}{l}\text { terletak pada } \\
\text { semua } \\
\text { variabel baik } \\
\text { variabel } \\
\text { dependen } \\
\text { maupun } \\
\text { independen }\end{array}$ & $\begin{array}{lr}\text { terletak pada } & \text { objek } \\
\text { penelitian } & \text { yaitu } \\
\text { penelitian } & \text { ini di } \\
\text { lakukan } & \text { terhadap } \\
\text { saham } & \text { Food and } \\
\text { beverage } & \text { sedangkan } \\
\text { penelitian } & \text { Yustiana } \\
\text { Ayu } & \text { dilakukan } \\
\text { terhadap } & \text { saham } \\
\text { perusahaan } & \\
\text { perbankan. } & \end{array}$ \\
\hline
\end{tabular}

\section{Hipotesis}

Berdasarkan latar belakang maka hipotesis yang diajukan dalam penelitian ini adalah:

Ha : Market value berpengaruh terhadap holding period

Ho : Market value tidak berpengaruh terhadap holding period

\section{Kerangka Pemikiran Teoritis}

Berdasarkan teori dan hasil-hasil dari penelitian terdahulu, faktor yang diidentifikasikan mempengaruhi holding period yaitu variabel market value. Untuk itu akan dilakukan pengujian sejauh mana pengaruh pengaruh variabel bebas tersebut terhadap holding period, sehingga kerangka pemikiran teoritis dalam penelitian ini dapat digambarkan sebagai berikut:

\section{Gambar 1}

Kerangka Pemikiran Teoritis

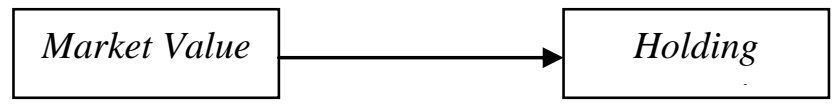

\section{METODE PENELITIAN}

\section{Jenis Penelitian}

Jenis data yang digunakan dalam penelitian ini adalah data kuantitatif dalam bentuk data sekunder. Data sekunder yaitu data yang telah di kumpulkan oleh lembaga pengumpul data ataupun pihak lain dan di publikasikan kepada masyarakat pengguna data. Data sekunder tersebut meliputi data-data volume transaksi, jumlah saham yang beredar yang di kumpulkan dari januari 2010 sampai desember 2012. Keseluruhan data diperoleh dari IDX montly statistic dan capital market directory yang diambil dari perpustakaan Pusat Informasi Pasar Modal (PIMP) manado serta www.idx.co.id.

\section{Teknik Pengumpulan Data}

Dalam melakukan pengumpulan data, di gunakan teknik pengumpulan data sekunder berupa data dokumentasi. Data dokumentasi adalah pengumpulan data dengan cara mengambil data-data dari catatan, dokumentasi, administrasi yang sesuai dengan masalah yang diteliti. Dalam hal ini dokumen-dokumen atau arsip-arsip dari lembaga yang diteliti (Nasution, 2003). Data tersebut dikumpulkan dari capital market directory 
periode 2010-2012 dan IDX montly statistic yang dikeluarkan setiap bulan selama periode penelitian serta peneliti juga mengakses ke- www.idx.co.id

\section{Populasi}

Menurut Kuncoro (2003) populasi adalah kelompok elemen yang lengkap, yang biasanya berupa orang, objek, transaksi, atau kejadian dimana kita tertarik untuk mempelajarinya atau menjadi objek penelitian. Populasi dalam penelitian ini adalah seluruh saham perusahaan manufaktur khususnya yang bergerak dalam food and beverage yang listing di BEI selama periode 2010 sampai desember 2012. Jumlah perusahaan manufaktur yang bergerak dalam bidang food and beverage yang terdaftar di BEI periode 2010 sampai dengan desember 2012 adalah 20 perusahaan.

\section{Sampel}

Kuncoro (2003) mendefinisikan sampel sebagai suatu himpunan bagian (subset) dari unit populasi. Dari ke-20 populasi diatas, peneliti menggunakan metode penggambilan sampel purposive sampling dengan tujuan untuk mendapatkan sampel yang representative dengan kriteria sebagai berikut:

1. Telah tercatat/ listed di bursa efek Indonesia sebagai emiten selama periode 2010-2012 secara konsisten.

2. Tercatat sebagai perusahaan manufaktur di bidang food and beverage

3. Tidak pernah suspend (dihentikan sementara) perdagangannya oleh BEI (selama waktu penelitian).

4. Harus tersedia volume transaksi pembelian dan penjualan saham selama periode 2010-2012.

Dari hasil pemilihan sampel secara purposive sampling, di peroleh 10 sampel perusahaan food and beverage yang memenuhi persyaratan dan sesuai untuk dijadikan sampel. Berikut ke-10 perusahaan di sajikan dalam bentuk tabel :

Tabel 2

Sampel Penelitian

\begin{tabular}{|c|l|l|}
\hline \multicolumn{1}{|l|}{ No } & Kode & Nama Perusahaan \\
\hline 1 & ADES & PT. Akasha Wira International Tbk \\
\hline 2 & CEKA & PT. Cahaya Kalbar Tbk \\
\hline 3 & DAVO & PT. Davomas Abadi Tbk \\
\hline 4 & INDF & PT. Indofood Sukses Makmur Tbk \\
\hline 5 & MYOR & PT. Mayora Indah Tbk \\
\hline 6 & STTP & PT. Siantar Top Tbk \\
\hline 7 & ULTJ & PT. Ultra Jaya Milk Tbk \\
\hline 8 & SMAR & PT. Smart, Tbk \\
\hline 9 & DLTA & PT. Delta Djakarta, Tbk \\
\hline 10 & PSDN & PT. Prashida Aneka Niaga, Tbk \\
\hline
\end{tabular}

Sumber : www.sahamok.com

\section{Model Regresi}

Teknik analisa yang digunakan dalam penelitian ini adalah dengan memakai teknik analisa regresi linier sederhana untuk memperoleh gambaran yang menyeluruh mengenai pengaruh variabel independen terhadap variabel dependent. Dalam hal ini untuk variabel dependentnya adalah holding period. Variabel-variabel independennya adalah market value saham perusahaan sepanjang periode observasi. Untuk menguji pengaruh market value terhadap holding period digunakan objek penelitian yaitu saham-saham perusahaan manufaktur khususnya yang bergerak di bidang food and beverage yang terdaftar di BEI selama periode 2010-2012.

Untuk mengetahui apakah ada pengaruh dari variabel-variabel independen terhadap variabel dependen maka digunakan model regresi linier sederhana, yang dirumuskan sebagai berikut:

\section{Pengujian Asumsi Klasik}

$$
\mathrm{Y}=\alpha+\beta_{1} \mathrm{X}_{1}+\varepsilon_{\mathrm{i}}
$$

Pada penelitian ini juga akan dilakukan pengujian pentimpangan asumsi klasik terhadap model regresi yeng telah diolah (Ghozali,2005) yang meliputi:
a. Uji Autokorelasi
b. Uji heteroskedastisitas 


\section{c. Uji Normalitas}

\section{Pengujian Hipotesis}

Model pengujian terhadap hipotesis yang diajukan dilakukan pengujian secara parsial dan pengujian secara simultan serta analisis koefisien determinasi $\left(R^{2}\right)$ (Ghozali, 2005). Pengujian hipotesis tersebut sebagai berikut:
a. Uji Statistik t
b. Uji F
c. Analisis Koefisien Determinasi $\left(\mathrm{R}^{2}\right)$

\section{Definisi Operasional Variabel}

Variabel dependen : Holding period

HldPer $_{\text {it }}=\frac{\text { jumlah saham beredar semester } \mathrm{T}}{\text { Volume transaksi semester T }}$

Variabel independen : Market value

$$
\text { MktViT }=\frac{\left[\sum_{t-1}^{N} \text { harga sahamit }\right]}{\mathrm{N}} \mathrm{X} \text { Jumlah saham beredar } i T
$$

\section{HASIL PENELITIAN DAN PEMBAHASAN}

\section{Hail Penelitian}

\section{Descriptive Statistics}

Dengan menggunakan bantuan Software Program SPSS Version 20.0, maka rata-rata hitung dan standar deviasi dari masing-masing variabel seperti yang ditunjukkan dalam Tabel 4.1, berikut ini :

\section{Tabel 3}

\begin{tabular}{|l|r|r|r|}
\multicolumn{5}{|c|}{ Descriptive Statistics } \\
\hline LNY & Mean & Std. Deviation & N \\
LNX & 16.8341 & 2.23563 & 28 \\
\hline
\end{tabular}

2. Pengujian Asumsi Klasik

a. Asumsi Klasik Normalitas

menunjukkan bahwa grafik Normal P-P of Regression Standardized Residual menggambarkan penyebaran data di sekitar garis diagonal dan penyebarannya mengikuti arah garis diagonal grafik tersebut, maka model regresi yang digunakan dalam penelitian ini memenuhi asumsi normalitas.

Gambar 2

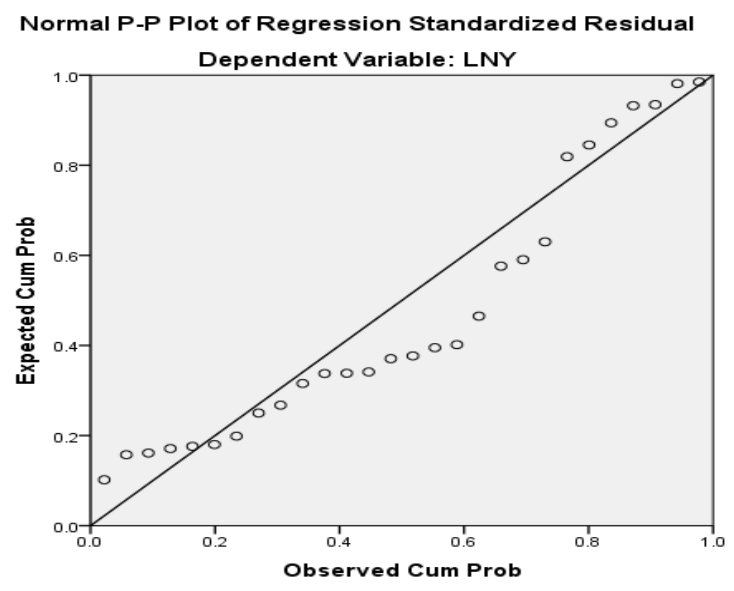


Tabel 4

Model Summaryb

\begin{tabular}{|l|r|r|r|r|r|}
\hline Model & \multicolumn{1}{|c|}{$\mathrm{R}$} & $\mathrm{R}$ Square & \multicolumn{1}{c|}{$\begin{array}{c}\text { Adjusted R } \\
\text { Square }\end{array}$} & $\begin{array}{l}\text { Std. Error of } \\
\text { the Estimate }\end{array}$ & $\begin{array}{l}\text { Durbin- } \\
\text { Watson }\end{array}$ \\
\hline 1 & $.063^{\mathrm{a}}$ & .004 & -.034 & 2.27363 & 1.762 \\
\hline
\end{tabular}

a. Predictors: (Constant), MARKET VALUE

b. Dependent Variable: HOLDING PERIOD

nilai Durbin Watson $(D W)$ sebesar 1.762 atau menunjukkan bahwa nilai D-W di antara -2 sampai +2 maka dapat disimpulkan tidak ada autokorelasi.

c. Asumsi Klasik Heteroskedastisitas

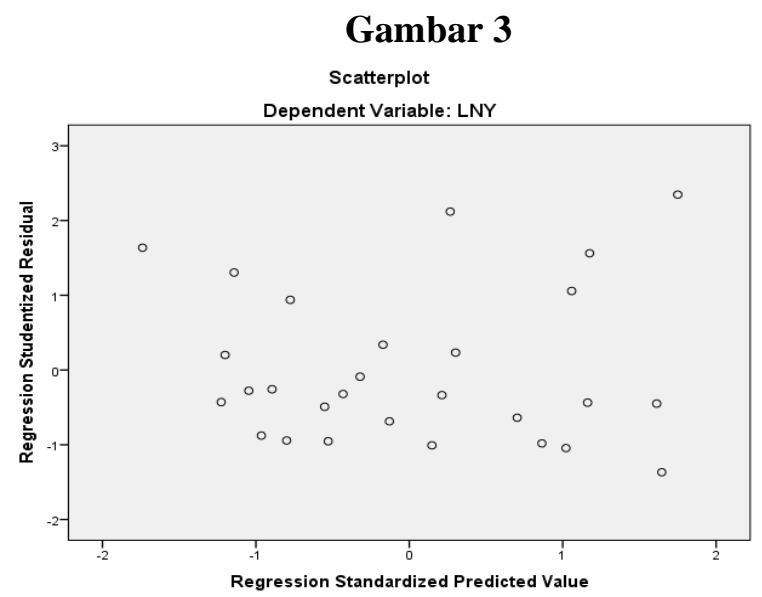

Dari gafik Scatterplot pada Gambar 4.2 terlihat bahwa titik-titik cukup menyebar di atas dan di bawah angka 0 (nol), sehingga dapat disimpulkan bahwa tidak terjadi heteroskedastisitas pada model regresi dalam penelitian ini.

3. Koefisien Korelasi dan Koefisien Determinasi

a. Koefisien Korelasi

koefisien korelasi linear yang dihasilkan antara Market Value $\left(\mathrm{X}_{1}\right)$ dengan Holding Period $(\mathrm{Y})$ adalah sebesar 0.063 artinya hubungan antara variabel MV Perusahaan dengan Holding Perioed Perusahaan Food and Beverages di Bursa Efek Indonesia bersifat positif.

Tabel 5

Correlations

\begin{tabular}{|ll|r|r|}
\hline & & $\begin{array}{c}\text { HOLDING } \\
\text { PERIOD }\end{array}$ & $\begin{array}{c}\text { MARKET } \\
\text { VALUE }\end{array}$ \\
\hline Pearson Correlation & HOLDING PERIOD & 1.000 & .063 \\
& MARKET VALUE & .063 & 1.000 \\
Sig. (1-tailed) & HOLDING PERIOD & .374 \\
$\mathrm{~N}$ & MARKET VALUE & .374 & .38 \\
& HOLDING PERIOD & 28 & 28 \\
& MARKET VALUE & 28 & 28 \\
\hline
\end{tabular}


b. Koefisien Determinan $\left(\mathrm{R}^{2}\right)$

Tabel 6

Model Summaryb

\begin{tabular}{|l|r|r|r|r|r|}
\hline Model & \multicolumn{1}{|c|}{$\mathrm{R}$} & $\mathrm{R}$ Square & \multicolumn{1}{c|}{$\begin{array}{c}\text { Adjusted R } \\
\text { Square }\end{array}$} & $\begin{array}{c}\text { Std. Error of the } \\
\text { Estimate }\end{array}$ & Durbin-Watson \\
\hline 1 & $.063^{\mathrm{a}}$ & .004 & -.034 & 2.27363 & 1.762 \\
\hline
\end{tabular}

a. Predictors: (Constant), MARKET VALUE

b. Dependent Variable: HOLDING PERIOD

nilai koefisien determinasi adalah 0,004 . Hal ini menunjukkan bahwa besarnya pengaruh variabel bebas, yaitu MV terhadap variabel terikat yaitu $H P$ yang dapat diterangkan oleh model persamaan dalam penelitian ini adalah sebesar $0.4 \%$, sedangkan sisanya sebesar 99,6\% diterangkan oleh faktor-faktor lain yang tidak dimasukkan dalam model regresi.

4. Analisis Regresi Sederhana

Tabel 7

Coefficientsa

\begin{tabular}{|c|c|c|c|c|c|}
\hline \multirow[t]{2}{*}{ Model } & \multicolumn{2}{|c|}{ Unstandardized Coefficients } & \multirow{2}{*}{$\begin{array}{c}\begin{array}{c}\text { Standardized } \\
\text { Coefficients }\end{array} \\
\text { Beta }\end{array}$} & \multirow[t]{2}{*}{$\mathrm{t}$} & \multirow[t]{2}{*}{ Sig. } \\
\hline & $\mathrm{B}$ & Std. Error & & & \\
\hline (Constant) & 14.651 & 6.747 & & 2.172 & .039 \\
\hline MARKET VALUE & .081 & .250 & .063 & .324 & .748 \\
\hline
\end{tabular}

a. Dependent Variable: HOLDING PERIOD

Dari hasil analisis dalam tabel diperoleh persamaan regresi linier sederhana sebagai berikut :

$$
Y=14.651+0.081 X_{1}
$$

Dari persamaan regresi linier sederhana di atas, dapat menginformasikan bahwa

- Nilai konstan sebesar 14.651 artinya jika variabel Market Value dianggap konstan, maka Holding Period saham (HP) akan sebesar 14.651.

- Koefisien $\mathrm{X}_{1}$ Market Value sebesar (MV) 0.081 yang berarti setiap penurunan variabel (MV) sebesar satu persen maka akan meningkatkan Holding period saham sebesar 0,081\% dengan asumsi faktorfaktor lain dianggap tetap (cateris paribus).

5. Penguujian Hipotesis

a. Uji t

Tabel 8

Coefficientsa

\begin{tabular}{|c|c|c|c|c|c|c|}
\hline \multirow{2}{*}{\multicolumn{2}{|c|}{ Model }} & \multicolumn{2}{|c|}{$\begin{array}{l}\text { Unstandardized } \\
\text { Coefficients }\end{array}$} & \multirow{2}{*}{$\begin{array}{c}\text { Standardized } \\
\text { Coefficients }\end{array}$} & \multirow[t]{2}{*}{$\mathrm{t}$} & \multirow[t]{2}{*}{ Sig. } \\
\hline & & B & Std. Error & & & \\
\hline \multirow[b]{2}{*}{1} & (Constant) & 14.651 & 6.747 & & 2.172 & .039 \\
\hline & $\begin{array}{l}\text { MARKET } \\
\text { VALUE }\end{array}$ & .081 & .250 & .063 & .324 & .748 \\
\hline
\end{tabular}

a. Dependent Variable: HOLDING PERIOD

Berdasarkan Tabel 4.6 diperoleh nilai $\mathrm{t}_{\text {hitung }}$ untuk MV $\left(\mathrm{X}_{1}\right)$ sebesar $0,324<$ dari nilai $\mathrm{t}_{\text {tabel }}$ sebesar 2,29 dan nilai signifikansi $\mathrm{P}=0,748>\alpha=0.05$, maka $\mathrm{H}_{\mathrm{a}}$ ditolak dan $\mathrm{H}_{0}$ diterima, artinya variable $\mathrm{MV}\left(\mathrm{X}_{1}\right)$ tidak berpengaruh terhadap Holding Period (HP) dan terdapat hubungan tidak searah. 
Tabel 9

ANOVAa

\begin{tabular}{|rl|r|r|r|r|r|}
\hline \multicolumn{1}{|l|}{ Model } & \multicolumn{1}{|c|}{$\begin{array}{c}\text { Sum of } \\
\text { Squares }\end{array}$} & Df & Mean Square & F & Sig. \\
\hline \multirow{2}{*}{1} & Regression & .544 & 1 & .544 & .105 & $.748^{\mathrm{b}}$ \\
& Residual & 134.404 & 26 & 5.169 & & \\
& Total & 134.947 & 27 & & & \\
\hline
\end{tabular}

a. Dependent Variable: HOLDING PERIOD

b. Predictors: (Constant), MARKET VALUE

Berdasarkan hasil uji $\mathrm{F}$ yang dapat dilihat pada Tabel 4.7, diperoleh $\mathrm{F}$ hitung sebesar 0.105 dengan tingkat signifikansi sebesar $0,748>\alpha=0,05$, maka $\mathrm{H}_{\mathrm{a}}$ ditolak artinya Market Value tidak berpengaruh terhadap Holding Period Saham.

\section{Pembahasan}

Berdasarkan hasil analisis regresi sederhana diperoleh persamaan regresi untuk variabel $\mathrm{Y}$ (Holding Period) dan variabel X1 (Market Value) $\mathrm{Y}=\mathrm{a}+\mathrm{b}_{1} \mathrm{X}_{1}+$ e adalah $\mathrm{Y}=14.651+0.081 \mathrm{X}_{1}$. Konstanta a sebesar 14.651 memberikan pengertian bahwa jika Market Value konstan atau sama dengan nol (0), maka besarnya Holding Period adalah 14.651 satuan. Bahwa perubahan Holding Period untuk tahun 2010-2012 hanya sebesar 14.651 berarti Market Value tidak berpengaruh terhadap Holding Period dalam perusahaan.

Berdasarkan hasil pengujian hipotesis uji t, maka dapat diketahui hasil $\mathrm{H}_{\mathrm{a}}$ ditolak dan $\mathrm{H}_{0}$ diterima artinya Market value tidak berpengaruh terhadap Holding Period, karena nilai signifikan 0,748 $>\alpha=0,05$.

Berdasarkan hasil koefisien determinasi $\left(\mathrm{R}^{2}\right)$ adalah sebesar 0,004, ini memberikan pengertian bahwa besarnya Holding Period pada perusahaan Food and beverages dapat dijelaskan oleh variabel independen yaitu Market Value adalah sebesar 0,4\% sementara sisanya 99,6\% dijelaskan oleh variabel lain yang tidak diteliti dalam penelitian ini.

Nilai koefisien variabel market value $(0,081)$ menandakan bahwa Variabel market value tidak berpengaruh signifikan terhadap holding period, hal ini berarti semakin tinggi Market value akan semakin pendek holding period meskipun demikian, tingkat signifikasi market value $(0,748)$ lebih besar dari tingkat signifikasi yang ditetapkan yaitu 0,05 untuk itu dapat disimpulkan bahwa variabel market value tidak berpengaruh signifikan terhadap holding period. Hal ini selaras dengan koefisien regresi market value yang sangat kecil yaitu hanya 0,081 . Ayu (2008).

Penelitian ini memiliki kesamaan dengan penelitian terdahulu yang dilakukan oleh Yustiana Andriani

\section{KESIMPULAN DAN SARAN}

\section{Kesimpulan}

Berdasarkan hasil penelitian dan pembahasan pada bab sebelumnya maka penulis dapat menarik kesimpulan sebagai berikut :

1. Untuk variabel $\mathrm{X}_{1}$ (Market Value), $\mathrm{H}_{\mathrm{a}}$ ditolak dan $\mathrm{H}_{0}$ diterima, artinya Market Value tidak berpengaruh terhadap Holding period.

2. Jadi, dapat dikatakan bahwa hipotesis yang diajukan oleh penulis yaitu Market Valuet tidak berpengaruh terhadap Holding Period dapat diterima.

\section{Saran}

Berdasarkan kesimpulan diatas, maka saran dari penulis adalah sebagai berikut.

1. Bagi manajemen perusahaan food and beverages, setelah mengetahui hasil dari penelitian ini. Sebaiknya lebih meningkatkan kinerja perusahaan, terutama pada periode penanaman saham yang lebih lama yang juga akan mempengaruhi harga pasar yang tinggi, demikian sebaliknya.

2. Hasil penelitian ini diharapkan dapat menjadi acuan bagi peneliti selanjutnya. Penulis menyarankan agar peneliti selanjutnya sebaiknya memperpanjang periode pengamatan serta menambahkan atau menggunakan variabel lain yang tidak terdapat dalam penelitian ini. 


\section{DAFTAR PUSTAKA}

Affandi, Untung dan Utama, Siddharta. (1998). Uji efisiensi bentuk setengah kuat Jakarta, Usahawan. Vol. 17. No. 1. P. 223-24

Atkins, Allen B. Dan Dly, Edward A. (2008). Transaction cost and holding period $\quad$ for common stock. The journal of finance.

Hadi, Helmi. (2008). Analisis pengaruh bid-ask spread, market value dan $\quad$ resiko saham terhadap Holding period Studi kasus pada saham LQ45 periode 2003-2005, UNDIP.

Harahap, Sofyan Syafri. 2011, Teori Akuntansi, edisi revisi 2011. PT Raja Grafindo Persada, Jakarta.

Horngren, C.T., Harrison Jr, W.T. 2007. Accounting: Pearson International Edition.

Ikatan Akuntan Indonesia, 2012. Standar Akuntansi Keuangan. Salemba Empat. Jakarta.

Kuncoro, M. (2003). Metode Riset Untuk Bisnis dan Ekonomi, Yogyakarta: UPP- $\quad$ AMP YKPN.

Martono dan Agus Harjito.2005. Manajemen Keuangan, cetakan kelima. Yogyakarta: Ekonasia.

Miapupita et. Al. (2003). Analisis Pengaruh Bid-Ask Spread, Market value dan resiko saham terhadap holsing period pada saham teraktif yang tercatat di Bursa Efek Jakarta Periode 2001-2002. Ventura. Vol 6. No. 2. P. 117-126.

Nasution, (2003). Metodologi research penelitian ilmiah, Jakarta: Bumi aksara

Soemarso S.R, 2005, Akuntansi Suatu Pengantar, Buku Dua. Salemba Empat. Jakarta.

Suharyadi, Purwanto. 2003. Statistik Untuk Ekonomi dan Keuangan Modern Buku I, Penerbit Salemba Empat. Jakarta.

Tandelilin, Eduardus. (2001). Analisis Investasi dan manajemen portofolio, Edisi $\quad$ pertama, $\quad$ BPFEYogyakarta

Weygandtdalam Yadiati, Wahyudi. (2006). Pengantar Akuntasi. Ed. 7-8. Jakarta

Yadiati, Winwin,. Wahyudi, Ilham. 2006. Pengantar Akuntansi. Ed. Revisi. Jakarta

Yuniningsih, (2008). Analisis faktor-faktor yang mempengaruhi transaction cost saham perusahaan yang terdaftar di BEI, Jurnal aplikasi manajemen. Vol. 6. No. 1.

Yustiana, (2008). Pengaruh bid-ask spread, market value dan risk of return terhadap holding period saham (studi kasus pada perusahaan perbankan yang go public di bursa efek Indonesia periode 20052007).

2013, “Indonesian Capital Market Directory", Jakarta

Website http://www.idx.co.id/beranda/publikasi/ringkasankinerjaperusahaantercatat.aspx

Website http://www.google.co.id/firefox?client=firefox-a\&rls=org.mozilla:en-US:official

Website http://www.iaiglobal.or.id/ppl/ppl.php?id=218 